\title{
GENDER AND SERVICES ECONOMY: LEBANESE WOMEN POSITION IN COMPLEX ARAB WORLD
}

\section{MONY TRAD}

\begin{tabular}{|c|c|}
\hline & $\begin{array}{l}\text { Cracow University of Economics, POLAND } \\
\text { e-mail: mt007@live.aul.edu.lb }\end{array}$ \\
\hline $\begin{array}{l}\text { RECEIVED } \\
\text { ACCEPTED }\end{array}$ & $\begin{array}{l}10 \text { November } 2015 \\
1 \text { April } 2016\end{array}$ \\
\hline $\begin{array}{l}\text { JEL } \\
\text { CLASSIFICATION }\end{array}$ & J16, J21, J71 \\
\hline KEYWORDS & gender, economy, women, Lebanon \\
\hline ABSTRACT & $\begin{array}{l}\text { The main context of this paper is to understand Lebanese women situation as part of the Middle Eastern region. } \\
\text { The drive of the article is a preliminary description of women's situation in the Arab region and evaluation of the } \\
\text { participation and role of females in the service economy in relation to the perceived obstacles; however, the } \\
\text { notable consideration was given to one selected country from the area, to be exact: Lebanon. It is based on } \\
\text { data and studies conducted in the area of gender and women involvement in Lebanon. Since Lebanese women } \\
\text { are part of the bigger Arab region, they are still confronted with numerous difficulties. They have been able to } \\
\text { enter the workforce; however, they still need to overcome numerous complications before they can reach full } \\
\text { participation capabilities. }\end{array}$ \\
\hline
\end{tabular}

\section{Introduction}

Enterprise is routinely described by way of commercial set-up advancement or as change inside of existing firms (e.g., Drucker, 1986).

According to Jamali, Sidani and Kobeissi (2008), over the previous decades, females have made significant steps, whether evaluated regarding expanded work power support, enhanced learning accomplishments, 
or advanced education rates. However, Davis (2012) argues that it has been completely understood that females' entrepreneurs face impressive separation, preference and gender stereotyping all through the world.

In a paper prepared by Fakih and Ghazalian (2015), expanding female occupation rates remains a fundamental thing on the work arrangement motivation of the Middle East and North Africa (MENA) locale. Despite that MENA nations have perceived fundamental accomplishments in advancing females' prosperity and societal position in the course of the last few decades, MENA's record regarding female job is as yet remaining behind numerous geo-monetary districts and stays one of the most reduced on the globe (Morrison et al., 2008; World Bank, 2011; International Labor Organization, 2014).

\section{Theoretical background}

\section{Female entreppeneurrship common beliefs}

The entrepreneurial talk has to a great extent focused upon monetary opportunities acknowledgment and rests regularly masculinized (Ahl, 2004; Ahl, Marlow, 2012).

Hanson (2009) contends that work is a development that has for the most part been joined with men (Bird, Brush, 2002), no inquiry in light of the way that men still constitute the greater part (around 66\%) of entrepreneurs around the globe paying little attention to the fast augmentation in females' business ownership.

Arenius and Minniti (2005) say we trust that inspecting nation specific components is a more compelling technique than simply looking at individual-level elements, especially for clarifying the significant difference in the rates of females' entrepreneurship crosswise nations.

Carter and Marlow (2003) refer that gender imbalance makes forces that may build or decline the level of women's interest in business. Furthermore, interest of females in entrepreneurial exercises may result of their expanded cooperation in the work advertise all in all. However, an expanding extent of female entrepreneurs might likewise come about because of work business separation or "unattainable rank" profession issues.

\section{Women in the Arab culture}

Based on CAWTAR/IFC (2007) report, females' business is dynamically seen as a vital variable for economic improvement and progression in the Middle East and North Africa nations.

According to Tlaiss (2015), regardless of the extended number of females' business people in the Arab world, the hypothesis of females in economic advancement in the district is significantly lower than in East or Central Asia, Latin America and Europe, with females owning just 13\% of the companies in the zone (World Bank, 2003-2006). Based on the same paper, the author claims that females' business is progressively pulling in the consideration of scholastics around the globe. In the context of the Arab World, the larger part of studies has been occupied with the joining of Islamic teachings and females' difficulties in business enterprise.

Furthermore, Yasin and Zimmerer (1995) describe that Islam has been referred to for the little part of females in the workforce. The truth is that Islam does not preclude women from taking part in productive business nor notwithstanding holding positions of power (Berger, 1962; Dodd, 1974; Youssef, 1971). The authors clarify that the deficiency of females from the business life in the traditionalist Arab subculture life may be tracked to the idea of "Aib" (disgrace). 
Chamlou (2008) describes that the locale likewise confronts another vital test - engaging females - especially in the money related and political circles, where their reinforcement remains the most unimportant of any district. Quite a few years' earlier, females were less organized and constituted a minor piece of the area's human capital. Obstacles that held them down obliged a sensibly littler cash related expense than today, now that females, following quite a while of interest in their education, represent almost a large portion of the district's human capital, particularly among the more youthful eras.

\section{Materials and methods}

This paper seeks to conduct a comprehensive survey of literature to think about the financial, social and legitimate setting to recognize female's circumstance in the Lebanese market and role in the economy. It is based on statistics and studies performed in the area of gender and women participation in Lebanon. In other words, it depends on secondary sources of the data related to the topic.

According to Jamali, Sidani and Safieddine (2005), Lebanon is an Arab country and a setting up associate from the Arab partnership. Additionally, it is a pluralistic nation by splendor. Regardless of being a little nation as far as populace size - Lebanon's populace right now remains at 3.6 million as indicated by late estimates, it has over 17 distinctive spiritual gatherings formally saw by the Lebanese administration. Lebanon in reality appears to suggest no special case to Middle-Eastern quality frameworks that underscore the part of females as moms and homemakers.

DeJong and Meyerson-Knox (2011) note that the states of Lebanese females are moreover really unique: A gender introduction examination of Lebanon's indicators reveals that Lebanese woman experience reasonably inconsistent measures of prosperity and education; however are inadequate with regards to a comparable vicinity in people in general circle.

\section{Results and discussion}

\section{Lebanese women circumstances in late years}

Based on Khalaf (2002) the commitment of the Lebanese female in the work business segment could be taken back to the beginning of the twentieth century, when numerous Lebanese women generally uneducated and in need, began working in the silk business and as househelps. The most purposive and bold ones among them emigrated on their own particular to the United States of America where they worked in production lines, leaving their spouses and youngsters behind, and this after the starvation that tormented Lebanon taking after World War I.

In a report prepared by the Consultation and Research Institute (2006) and based on Al-Khatib (1984), Lebanese common society saw a multiplication of women's gatherings reinforcing that required females' strengthening subsequent to the mid twentieth century. They were affected by different western, patriot and communist talks for improving women's part in the family and society.

Based on Tailfer (2010), females' commitment to the workforce has expanded impressively since the 70's in spite of long years of war and progressive clashes that have tormented Lebanon. 


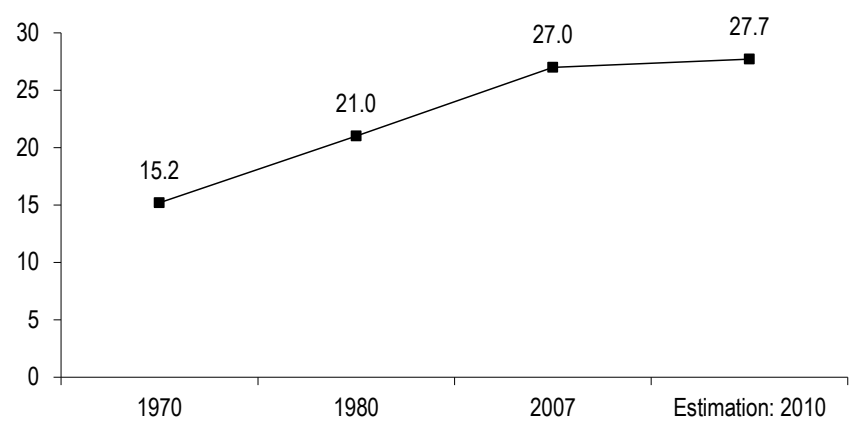

Figure 1. Evolution of women's role in the workforce in formal economy between 1970 and 2010 (\%)

Source: Tailfer (2010).

The above figure provides a general idea about the development in the part of Lebanese females in the work power subsequent to 1970. In spite of the fact that the numbers show an increase throughout the years from around $15 \%$ to approximately $28 \%$ in 2010 , it is essential to mention that the ratio is still not very encouraging and both the private sector as well as the government needs to make more efforts to improve the situation.

Furthermore, numerous studies have been conducted throughout the years on Lebanese females. In one of the studies, Sha'rani (2004) explains that women investment in broad everyday life additionally stays marginal. The following table explains females' restricted interest in choice making positions at distinctive levels.

Table 1. Females Public Sector Involvement in Lebanon

\begin{tabular}{ll}
\hline Individuals from Legislature & 3 females out of 128 individuals from legislature \\
Diplomats & 2 females out of 53 diplomats \\
Executive General & 3 females out of 22 executives general \\
Senior member in the Lebanese University & 1 female out of 13 senior members \\
Individuals from the Community Board & 139 females out of 8,461 community board members \\
President of Community Board & 2 females out of 736 community board presidents \\
The Instructors' Union & 1 female beyond 12 panel associates \\
The Subordinate Instructors' Union & 2 females beyond 18 panel memberships \\
The Engineers' Association & No female on the association's panel \\
The Doctors' Association & No female on the amalgamation's panel \\
The Pharmacologists' Association & 1 female was two times selected as head \\
The Dentists' Association & 1 female was one time chosen as its leader \\
The Bar Association & 2 females on the panel \\
Magistrate in the National Counseling Assembly & 6 females beyond 365 magistrates \\
Magistrate in the Legal Law Court & $18 \%$ of the 365 magistrates \\
\hline
\end{tabular}

Source: Sha'rani (2004).

The public sector is an attractive source of jobs in Lebanon due to numerous reasons including good salaries at different levels as well as the social security it provides for its full time employees. The above table shows statistics referred to in the State Article about the Circumstances of Females in Lebanon in 2000. It should be noted, 
however, that the situation nowadays is to a large extent similar with only some exceptions. The above jobs can all be ranked as high level positions; yet, the numbers are not very encouraging. Three women out of 128 parliament members tell that the voice of females on the country-level decision making does not approximately exist. Moreover, although women in Lebanon have the desire to learn and acquire high educational levels, they are not given the chance to prove their skills in first-level ranked positions and representative boards. The above numbers do not reveal the fact the females in Lebanon are not capable, nonetheless, it clarifies that women are given equal chances and we still need many steps forward. Also, it should be illustrated that since the year this numbers were considered, the circumstances did not alter a lot, and only certain number changed such as the number of directors in the Lebanese University.

Moreover, in the course of similar studies and based on Al-Jouni (2010), the information on education are vital to observing social and fiscal advancement for the most part, and gender orientation uniformity. The following part will present data on education in Lebanon.

Tahle 2. Membership Level at Basic and Subordinate Stages 2007

\begin{tabular}{lrc}
\cline { 2 - 3 } & Female & Male \\
\hline Gross Enrollment Rate at Elementary level & 105.1 & 110.1 \\
Net Enrollment Rate at Elementary level & 93.4 & 92.8 \\
Net Enrollment Rate at Secondary level & 56.5 & 50.7 \\
\hline
\end{tabular}

Source: Al-Jouni (2010).

Table 2 compares the level of enrollment among man and woman at two educational levels: elementary and secondary. The net rate at both levels shows more female than male and especially at the subordinate level. This indicates that woman in Lebanon has a strong tendency to learn and reach advanced levels. This should be an encouraging factor for those in power to help females benefit from various opportunities and work hardly to minimize the gender gap. Gross enrollment rate (GER) can surpass $100 \%$ because of the consideration of over-matured and under-matured understudies in view of right on time or late school passage and grade redundancy.

\section{Conclusions}

The Lebanese women have always been known for their ambition and desire to succeed and prosper internally as mothers and housewives and externally as part of the workforce. They have a big tendency to learn and acquire knowledge. It is very common to see Lebanese females enrolled in different fields of study in universities. Although the situation of Lebanese women has improved throughout the years, numerous steps are still needed and various obstacles must be overcome to improve their participation as major contributors socially and economically and to diminish the gender gap that is still evident in diverse areas. What is necessary and important for Lebanese females is:

- To have social support including family, friends, and mainly husbands in the cases of married females.

- To receive a sufficient amount of facilities from both private and public sectors including access to education and equal employment opportunities.

- To witness respect for and implementation of women's rights laws and agreements. 
- To improve presence and share of females in decision making positions and give them chance to be part of the change process.

As stated by Tlaiss (2015), although the developments that the Arab world is experiencing and endeavors to enhance gender orientation balance, more ought to be done. Gender orientation societies and structures, alongside their definitions and impression of masculinity and its different structures, must to be analyzed as built through social and financial encounters.

Finally, based on a study done by Tlaiss and Kauser (2011), it would be astonishing to see some examination done on the impact of the particular social classes in Lebanon on the work advancement of females. Besides, the influence of religion, society and organization are crucial to a present's position of females in Lebanon.

\section{References}

Ahl, H. (2004). The Scientific Reproduction of Gender Inequality: A Discourse Analysis of Research Texts on Women's Entrepreneurship. Stockholm: Liber.

Ahl, H. \& Marlow, S. (2012). Exploring the dynamics of gender, feminism and entrepreneurship: advancing debate to escape a dead end? Organization, 19 (5), 543-562.

Al-Jouni, I. (2010). Gender Statistics in Lebanon Current situation and Future needs. Central Administration for Statistics. Available at: http://www.cas.gov.lb.

Al-Khatib, H. (1984). The historical evolution of the women's movement in Lebanon and its relationship with the Arab world: 1800-1975. Beirut, Dar al-Hadatha lil 171.

Arenius, P. \& Minniti, M. (2005). Perceptual Variables and Nascent Entrepreneurship. Small Business Economics, 24, $233-247$.

Bird, B. \& Brush, C. (2002). A gendered perspective on organizational creation. Entrepreneurship Theory and Practice, 26 (3), $41-65$.

Berger, M. (1962). The Arab World Today, Doubleday. New York, NY.

Carter, S. \& Marlow, S. (2003). Accounting for change: Professionalism as a challenge to gender disadvantage in entrepreneurship. In: J. Butler (ed.), New perspectives on women entrepreneurs (pp. 181-202). Greenwich: CT: Information Age Publishing.

CAWTAR/IFC (2007). Women Entrepreneurs in the Middle East and North Africa: Characteristics, Contributions and Challenges. Available at: http://www.ifc.org.

Chamlou, N. (2008). The Environment for Women's Entrepreneurship in the Middle East and North Africa. The International Bank for Reconstruction and Development/The World Bank. DOI: 10.1596/978-0-8213-7495-5.

Davis, P. (2012). The global training deficit: the scarcity of formal and informal professional development opportunities for women entrepreneurs. Industrial and Commercial Training, 44 (1), 19-25. Available at: http://dx.doi.org/10.1108/00197851211193381.

DeJong, J. \& Meyerson-Knox, S. (2011). Lebanon: An Overview Context, Evolving Demographics for Women, Sexual and Reproductive Health, Poverty and Women, Gender and Rights. UNFPA Policy Briefs.

Dodd, P.C. (1974). The effect of religious affiliation of woman's role in Middle East Arab society. Journal of Comparative Family Studies, 5 (2), 117-129.

Drucker, P. (1986). Innovation and Entrepreneurship. New York: Harpercollins Publishers.

Fakih, A. \& Ghazalian, P. (2015). Female employment in MENA's manufacturing sector: the implications of firm-related and national factor. Econ Change Restruct, 48, 37-69. DOI: 10.1007/s10644-014-9155-1.

Hanson, S. (2009). Changing Places through Women's Entrepreneurship. Economic Geography, 85 (3), 245-267.

International Labor Organization (ILO) (2014). Global employment trends 2014: risk of jobless recovery. International Labor Organization, Geneva.

Jamali, D., Sidani, Y. \& Safieddine, A. (2005). Constraints facing working women in Lebanon: an insider view. Women in Management Review, 20 (8), 581-594. DOI: 10.1108/09649420510635213.

Jamali, D., Sidani, Y. \& Kobeissi, A. (2008). The gender pay gap revisited: insights from a developing country context. Gender in Management: An International Journal, 23 (4), 230-246. DOI: 10.1108/17542410810878059.

Khalaf, M. (2002). Women's Employment in Lebanon and its Impact on their Status. Global, Area and International Archive. 
Morrison, A.R, Sabarwal, S., Sjöblom M. (2008). The state of world progress, 1990-2007. In: M. Buvinić, A.R. Morrison, A.W. OfosuAmaah, M. Sjöblom (eds.), Equality for women: where do we stand on the millennium development goals 3? Washington, DC: The International Bank for Reconstruction and Development/The World Bank.

Sha'rani, A. (2004). The Lebanese women: reality and aspirations. Available at: www.nclw.org.lb/lebanesemid.cfm.

Tailfer, D. (2010). Women and Economic Power in Lebanon: The legal framework and challenges to women's economic empowerment. Collective for Research and Training on Development-CRTD-A. Available at: http://crtda.org.lb/sites/default/files/Women\%20 in $\% 20$ the $\% 20$ Lebanese\%20Economy.pdf.

Tlaiss, H. \& Kauser, S. (2011). The impact of gender, family, and work on the career advancement of Lebanese women managers. Gender in Management: An International Journal, 26 (1), 8 - 36. DOI: 10.1108/17542411111109291.

Tlaiss, H. (2015). Neither-nor: career success of women in an Arab Middle Eastern context. Employee Relations, 37 (5), 525-546. DOI: 10.1108/ER-03-2014-0028.

World Bank (2003-2006). The Environment for women's entrepreneurship in the Middle East and North Africa. Washington, DC: World Bank.

World Bank (2011). Capabilities, opportunities and participation: gender equality and development in the Middle East and North Africa region. The World Bank, Washington, DC.

Yasin, M. \& Zimmerer, T. (1995). Achieving new venture success in the emerging Arab countries: a study of comparative cultures and strategies in two segments of the Arab world. Cross Cultural Management: An International Journal, 2 (4), 3-14. DOI: 10.1108/ eb008396.

Youssef, N.H. (1971). Social structure and the female labor force: the case of women workers in Muslim Middle Eastern countries. Demography, 8 (4), 427-439.

Cite this article aS: Trad, M. (2016). Gender and services economy: Lebanese women position in complex Arab world. European Journal of Service Management, 18 (2), 47-53. DOI: 10.18276/ejsm.2016.18-06. 
